\title{
Cup Dosing Unit
}

National Cancer Institute

\section{Source}

National Cancer Institute. Cup Dosing Unit. NCI Thesaurus. Code C54703.

A dosing unit equal to the amount of active ing redient(s) contained in a cup. 